\title{
Effects of Photobiomodulation on Experimental Bone Repair in Animal models: a Systematic Review
}

\author{
Otavio Marino dos Santos Neto ${ }^{1}$, Lothar Lilge ${ }^{2,3}$, Carla Andreotti Damante ${ }^{4}$, Ana Carla Campos ${ }^{5}$, João Paulo Mardegan Issa ${ }^{5}$ \\ 'São Paulo University (USP), School of Dentistry, Department of Dental Materials and Prosthodontics, Ribeirão Preto, SP, Brazil. \\ 2Princess Margaret Cancer Centre, University Health Network, 101 College Street, Toronto M5G1L7, ON, Canada. \\ ${ }^{3}$ University of Toronto, Department of Medical Biophysics, Toronto, ON, Canada. \\ 4São Paulo University (USP), School of Dentistry, Department of Prosthodontics and Periodontics, Bauru, SP, Brazil. \\ ${ }^{5}$ São Paulo University (USP), School of Dentistry, Department of Basic and Oral Biology, Ribeirão Preto, SP, Brazil.
}

Disclose and conflicts of interest: none to be declared by all authors

\section{ABSTRACT}

Introduction: photobiomodulation was showed positive effects on bone healing, however, several studies search safe protocols and dosimetry, beyond good experimental models. Thus, the present study aimed to conduct a systematic review of photobiomodulation (PBM) effects on bone healing increase, focusing on animal experimental models.

Revision: the studies search on the PBM use in bone repair was carried out in the PubMed / MEDLINE and Lilacs databases, excluding studies that included systemic conditions and biomaterials or medications use. Sixteen studies were selected, within the inclusion and exclusion criteria stipulated. Animal models included rats $(n=14)$ and rabbits $(n=2)$. The laser parameters applied ranging between $650 \mathrm{~nm}$ and $830 \mathrm{~nm}$ and the power density ranging from $0.03 \mathrm{~W}$ to $6 \mathrm{~W}$. Animal models were mainly concentrated in rodents, and the most utilized defect type was the tibial bone defect with $2.5 \mathrm{~mm}$ of diameter. Conclusion: through this review we concluded that the location and size of the defects, as well as the laser irradiation parameters are diverse and have shown the lack of consensus on the topic, however the results for using PBM therapy are encouraging.

Keywords: Low-level laser therapy; Photobiomodulation therapy; Bone repair; Bone defects; Animal models.

\section{Introduction}

Surgical procedures, trauma, dental extractions, pathologies and anomalies are answerable for bone defects creation, constituting an important field of bone biology investigation ${ }^{1}$. The bone repair process is defined as a regenerative process, involving different stages of development, including the action of different types of cells, proteins, genes which in the end reestablishes bone tissue integrity. According to Gartner and Hiatt ${ }^{2}$, a bone fracture generates damage and destruction to the bone matrix, as well as the cells death, periosteum and endosteum cracks and possible displacement of the ends of the broken bone. However, the bone repair process is slow and depends on neovascularization and mineral components, such as calcium and phosphorus ${ }^{3,4}$. In this context, critical bone defects are a constant concern in the field of bone biology, because due to their larger size they tend to have an unfavorable prognosis, and the repair success depends on factors such as favorable biomechanical conditions, surgical technique employed, systemic factors and nutrition ${ }^{5}$.

The search for new therapeutic solutions that favor bone repair is a constant effort in medicine. Photobiostimulation therapy (PBM) has shown encouraging results on in vitro and in vivo studies regarding bone repair, suggesting that PBM promotes the acceleration of this process ${ }^{6}$. However, we must consider that the studies are not conclusive as to a safe and precise protocol for its application, since the different methodologies used vary in terms of dose, energy and fluency. Low fluences are constantly used, as it is considered that high doses can inhibit and damage the repair process ${ }^{7}$.

Several animal models are used for bone tissue studies, such as the use of rats, mice, dogs, sheep, goats and pigs, allowing human conditions simulation in an in vivo environment. Defects that simulate orthopedic conditions are created in these animals, and the defects are usually located in the femur, calvaria or ulna. However, a careful analysis is required for animal selection, taking into account its physiological behavior, acquisition costs, ethical factors and tolerance to captivity. In addition, the selected animal must have biological responses similar to that of humans ${ }^{5}$.

The present study reviewed the literature aiming to contribute to the understanding of the effects of laser-based photobiomodulation (PBM), previously referred to as low-level laser therapy (LLLT), on the acceleration of bone healing in experimental models, discussing the advantages and disadvantages of the different experimental models used for the study of bone repair. 


\section{Materials and Methods}

\section{Search strategy}

This study has regarded for the Preferred Reporting Items for Systematic review and Meta-Analysis Protocols (PRISMA-P) checklist. The studies selection for this review included ((Low-level laser therapy) AND (Bone repair) AND (Animal models)) as keywords on MEDLINE and databases. The research was limited to English-language studies published until December 2020. After the selection of interest studies, an analysis of the bibliographic references was carried out, so that studies not found in the database search were included.

\section{Inclusion criteria}

The inclusion criteria consisted in:

1. Studies published until December 2020;

2. Studies in vivo, involving different animals and the creation of critical bone defects and reparing using the PBM;

3. Studies that adequately describe the PBM parameters: (wavelength, average output power, beam area, power density or irradiance $\left(\mathrm{W} \mathrm{cm}^{-2}\right)$, energy density or radiant exposure $\left(\mathrm{J} \mathrm{cm}^{-2}\right)$, energy per point
$(\mathrm{J})$, total energy (J), number of irradiated points and irradiation time per point (s) In some studies, it was necessary to calculate some of these parameters with the information provided.

\section{Exclusion criteria}

The exclusion criteria consisted in:

1. Clinical trials and in vitro studies;

2. Review studies;

3. Studies involving PBM but involving the use of grafts, biomaterials, drugs;

4. Studies involving systemic conditions;

5. Studies in which the PBM therapy parameters have not been adequately described.

Fig. 1 presents the selecting studies process.

\section{Results:}

Seventeen studies were selected based on the inclusion and exclusion criteria. The studies were analyzed and organized according publication year.

1) Laser parameters

For the 16 studies selected, all irradiation parameters are summarized in Table 1.

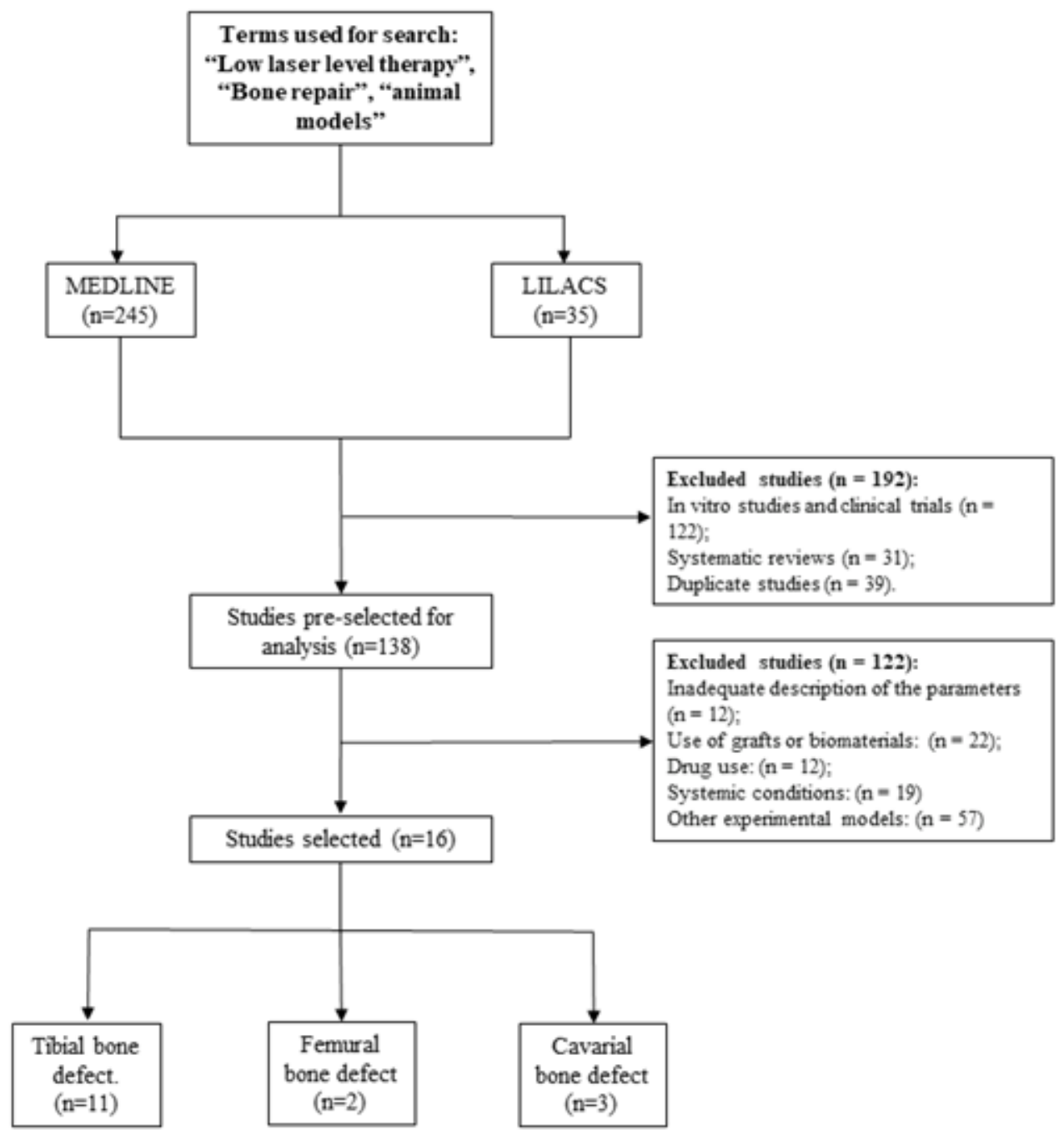

Figure 1. Flow chart showing the study selection process 
Table 1. Laser parameters used in included studies

\begin{tabular}{|c|c|c|c|c|}
\hline Author & Therapy & Laser Type & PBM parameters & Energy [J] \\
\hline Magri et al., $2019^{18}$ & PBM & GaAlAs & $\begin{array}{l}\text { Wavelength } 808 \mathrm{~nm} \text { (infrared), Laser Continuous output laser frequency, } \\
100 \mathrm{~mW} \text { optical outpout, Power density } 3.57 \mathrm{~W} / \mathrm{cm}^{2} \text {, Dose } 30 \mathrm{~J} / \mathrm{cm}^{2} \text {, Timer } \\
\text { per point } 8 \mathrm{~s} \text {, Spot area } 0.028 \mathrm{~cm}^{2} \text {. }\end{array}$ & $\begin{array}{l}\text { Energy } \\
0.84 \mathrm{~J}\end{array}$ \\
\hline Atasoy et al., $2017^{21}$ & PBM & GaAlAs & $\begin{array}{l}\text { Irradiation was performed in continuous wave mode for } 10 \text { seconds } \\
\text { with an optical output power of } 1.5,3 \text { and } 6 \mathrm{~W} \text {, and the energy densities } \\
\text { applied were } 5 \mathrm{~J} \cdot \mathrm{cm}^{-2}, 10 \mathrm{~J} \cdot \mathrm{cm}^{-2} \text { and } 20 \mathrm{~J} \cdot \mathrm{cm}^{-2} \text {, respectively. Beam diameter } \\
30 \mathrm{~mm} \text {. }\end{array}$ & - \\
\hline Tim et al., $2016^{8}$ & PBM & GaAlAs & $\begin{array}{l}\text { Continuous wavelength }(\lambda) \text { of } 830 \mathrm{~nm}, 0.028 \mathrm{~cm} 2 \text { spot area, } 30 \mathrm{~mW}, 94 \mathrm{~s} \text {, } \\
2.8 \mathrm{~J}, 1.071 \mathrm{~W} / \mathrm{cm}^{2} \text {, and } 100 \mathrm{~J} \cdot \mathrm{cm}^{-2} \text { was used }\end{array}$ & 0.1881 \\
\hline Acar et al., $2016^{3}$ & PBM + LIPUS & GaAlAs & $\begin{array}{l}\text { A gallium-aluminum-arsenic (GaAlAs) diode laser was applied at a con- } \\
\text { tinuous wavelength of } 810 \mathrm{~nm} \text {, a power output of } 0.1 \mathrm{~W} \text { and } 120 \mathrm{~s} \text {. A dose } \\
\text { of } 4 \mathrm{~J} \cdot \mathrm{cm}^{-2} \text { was applied to the defect per session. }\end{array}$ & \\
\hline Tim et al., $2016^{9}$ & PBM & GaAlAs & $\begin{array}{l}\mathrm{CW}, 830 \mathrm{~nm}, 0.6 \mathrm{~mm} \text { beam diameter, } 30 \mathrm{~mW}, 94 \mathrm{~s}, 2.8 \mathrm{~J} \text { was used in this } \\
\text { study }\end{array}$ & 2.8 \\
\hline Tim et al., $2015^{10}$ & PBM & GaAlAs & $\begin{array}{l}\text { Ga-Al-As, } 830 \mathrm{~nm} \text { continuous wavelength, } 0.6 \mathrm{~mm} \text { beam diameter, } 0.028 \\
\mathrm{~cm} 2 \text { spot area, power } 30 \mathrm{~mW} \text {, time } 94 \mathrm{~S} \text {, energy } 2.8 \mathrm{~J} \text {, and fluency } 1000 \\
\mathrm{~J} \cdot \mathrm{cm}^{-2}\end{array}$ & 2.8 \\
\hline Batista et al., $2015^{12}$ & PBM & GaAlAs & $\begin{array}{l}\text { With a continuous wavelength of } 830 \mathrm{~nm}, 50 \mathrm{~mW} \text { of potency and } 0.028 \\
\mathrm{~cm} 2 \text { spot area. The application was punctual, with a } 6-\mathrm{J} \text { [density energy } \\
(\mathrm{DE}) 210 \mathrm{~J} \cdot \mathrm{cm}-2 \text { ] dose per session during } 2 \mathrm{~min}\end{array}$ & 6 \\
\hline Marques et al., $2014^{20}$ & PBM & GaAlAs & $\begin{array}{l}\text { Protocol 1: distance of } 1 \mathrm{~mm} \text { from the edge, with a fluence of } 16 \mathrm{~J} \cdot \mathrm{cm}-2 \\
\text { (power } 50 \mathrm{~mW} \text {, exposure time of 9s) } \\
\text { Protocol 2: One application with, with a fluence of } 3.7 \mathrm{~J} \cdot \mathrm{cm}-2 \text { (power } 50 \\
\mathrm{~mW} \text {, exposure time of } 3 \mathrm{~s} \text { ) and } 2 \text { applications with } 16 \mathrm{~J} \cdot \mathrm{cm}^{-2} \text {. }\end{array}$ & - \\
\hline Tim et al, $2014^{23}$ & PBM & GaAlAs & $\begin{array}{l}830 \mathrm{~nm} \text { (Teralaser, DMC }{ }^{\circledR}, \text { São Carlos, SP, Brazil), continuous wavelength, } \\
0.028 \mathrm{~cm} 2 \text { spot area, } 100 \mathrm{~mW}, 3.57 \mathrm{~W} \cdot \mathrm{cm}^{-2}, 34 \mathrm{~S}, 3.4 \mathrm{~J} \text {, and } 120 \mathrm{~J} \cdot \mathrm{cm}-2 \text { was } \\
\text { used in this study }\end{array}$ & 3.7 \\
\hline $\begin{array}{l}\text { de Oliveira et al, } \\
2014^{16}\end{array}$ & PBM & GaAlAs & $\begin{array}{l}\text { 830 nm, output power }=50 \mathrm{~mW} \text {, energy density }=2.5 \mathrm{~J} / \mathrm{cm}^{2} \text {, diameter of } \\
\text { fiber-optic output }=9 \mathrm{~mm}, \mathrm{t}=45 \mathrm{~s}\end{array}$ & - \\
\hline $\begin{array}{l}\text { Fernandes et al, } \\
2013^{11}\end{array}$ & PBM & GaAlAs & $\begin{array}{l}\text { Laser } 830 \mathrm{~nm}, 30 \mathrm{~mW} \text {, continuous wavelength, } 0.028 \mathrm{~cm}^{2} \text { spot area, } 1.071 \\
\mathrm{~W} \cdot \mathrm{cm}^{-2}, 1 \mathrm{~min} \text { and } 34 \mathrm{~s}, 2.8 \mathrm{~J}, 100 \mathrm{~J} \cdot \mathrm{cm}^{-2}\end{array}$ & 2.8 \\
\hline Peccin et al, $2013^{19}$ & $\begin{array}{l}\text { Helium-laser } \\
\text { (PBM) }\end{array}$ & $\mathrm{He}-\mathrm{Ne}$ & $\begin{array}{l}\text { A low-energy He-Ne laser, } 632 \mathrm{~nm} \text {, continuous wavelength, } 0.0314 \mathrm{~cm}^{2}, 1 \\
\mathrm{~min}, 6 \mathrm{~J} \cdot \mathrm{cm}^{-2} \text { (Biosistemas, SP, Brazil) was used }\end{array}$ & 0.1884 \\
\hline Barbosa et al, $2013^{31}$ & PBM & $\begin{array}{l}\text { InGaAlP } \\
\text { GaAlAs }\end{array}$ & $\begin{array}{l}\text { The equipment used in the study was a laser, Flash Laser III (DMC } \\
\text { Equipamentos Ltda, São Carlos, SP), which operates in two wavelengths, } \\
\text { between } 660 \text { and } 690 \mathrm{~nm} \text { (red laser, mid-activity: InGaAIP) used for } \\
\text { the group II and between } 790 \text { and } 830 \mathrm{~nm} \text { (infrared laser, mid-activity: } \\
\text { GaAlAs) applied to group III. The PBM was applied directly on the injury, } \\
\text { with the hand piece at a } 90^{\circ} \text { angle, perpendicularly positioned on the } \\
\text { wound, using punctual technique according the protocol described } \\
\text { (Laser mode Continuous Optical output } 100 \mathrm{~mW}, 0.028 \mathrm{~cm}^{2} \mathrm{spot} \text { area; } \\
\text { Power density } 3.5 \mathrm{~J} \cdot \mathrm{cm}^{-2} \text {; Energy } 4 \mathrm{~J} \text {; Energy density } 140 \mathrm{~J} \cdot \mathrm{cm}^{-2} \text { ). Time } 40 \mathrm{~s} \text {. } \\
\text { Number of points } 1\end{array}$ & 4 \\
\hline $\begin{array}{l}\text { Fávaro-Pípi et al. } \\
2010^{22}\end{array}$ & $\begin{array}{l}\text { Low-intensity } \\
\text { pulsed } \\
\text { ultrasound } \\
\text { and PBM }\end{array}$ & $\begin{array}{l}\text { Low-intensity } \\
\text { pulsed } \\
\text { ultrasound } \\
\text { GaAlAs }\end{array}$ & $\begin{array}{l}\text { Both treatments were performed through the contact technique } \\
\text { on the skin, above the site of the bone injury. Low-intensity pulsed } \\
\text { ultrasound ( } 1.5 \mathrm{MHz}, 1: 4 \text { duty cycle, intensity SATA } 30 \mathrm{~mW} \cdot \mathrm{cm}^{-2}, 20 \mathrm{~min} / \\
\text { session, stationary mode application) was used. The animals of the laser } \\
\text { group were treated with a low-energy Ga-Al-As laser (Tera laser, DMC, } \\
\text { equipamentos São Carlos, SP, Brazil), } 830 \mathrm{~nm} \text {, continuous-wave, } 0.028 \\
\mathrm{~cm}^{2} \text { spot area, } 50 \mathrm{~W} \cdot \mathrm{cm}^{-2}, 50 \mathrm{~J} \cdot \mathrm{cm}^{-2}, 30 \mathrm{~mW} \text {, with a irradiation time of } 47 \mathrm{~s} \\
\text { (total energy per point } 0.51 \mathrm{~J} \text { ) }\end{array}$ & 0.5 \\
\hline $\begin{array}{l}\text { Matsumoto et al., } \\
2009^{17}\end{array}$ & PBM & GaAlAs & $\begin{array}{l}\text { A low-energy gallium arsenide laser, } 735 \mathrm{~nm} \text { in wavelength (DMC, Sao } \\
\text { Carlos, Brazil), continuous wave, } 3 \mathrm{~mm} \text { laser beam diameter, at } 16 \mathrm{~J} / \mathrm{cm}^{2} \text {, } \\
\text { with irradiation time of } 1 \mathrm{~min} \text {, was used in this experiment }\end{array}$ & 0.7065 \\
\hline Blaya et al., $2008^{15}$ & $\begin{array}{l}\text { PBM }(830 \mathrm{~nm}) \\
\operatorname{PBM}(685 \mathrm{~nm})\end{array}$ & $\begin{array}{l}\text { GaAlAs } \\
\text { InGaAIP }\end{array}$ & $\begin{array}{l}\text { Group I (GaAlAs): } 830 \mathrm{~nm} \text { continuous. Dose:10 J.cm-2; } 50 \mathrm{~mW} \text {. } \\
\text { Group I: InGaAIP: } 685 \mathrm{~nm} \text {. Dose: } 10 \mathrm{~J} \cdot \mathrm{cm}^{-2} ; 50 \mathrm{~mW}\end{array}$ & - \\
\hline
\end{tabular}




\section{1) Laser wavelengths ( $\mathrm{nm})$}

According to the analyzed manuscripts, the GaAlAs laser wavelength varies between 650 to $830 \mathrm{~nm}$, with the length of $830 \mathrm{~nm}$ being the most used ${ }^{8-16}$. Another studies evaluated GaAlAs $(735 \mathrm{~nm})^{17}$, GaAlAs $(808 \mathrm{~nm})^{18}, \mathrm{He}-\mathrm{Ne}(632 \mathrm{~nm})^{19}$, InGaAlP $(660-690 \mathrm{~nm})$ ${ }^{13}$, InGaAlP $(685 \mathrm{~nm})^{15}$. Two studies not described the laser wavelengths $\mathrm{s}^{20,21}$. However, all wavelengths are within the 'optical window' where light penetration into tissue is largest.

\section{2) Optical power and power density or irradiance $\left(\mathrm{W} \cdot \mathrm{cm}^{-2}\right)$}

Most PBM studies have described optical power, ranging from $0.03 \mathrm{~W}$ to $6 \mathrm{~W}$, with $50 \mathrm{~mW}$ being used more. Several studies mentioned the power density, among them, $0.03 \mathrm{~W}^{8-11,22}, 0.05 \mathrm{~W}^{12,15,16,20}, 0.1 \mathrm{~W}^{3,13,18,23}, 1.5$, 3 and $6 \mathrm{~W}^{21}$. Even though power density or irradiance $\mathrm{W} \cdot \mathrm{cm}-2$ represents an important parameter in PBM, two studies not described this parameter17,19. 0.3)

Beam diameter

Only two studies described the beam diameter of $0.6 \mathrm{~mm}^{9,10}$.

\section{4) Spot area}

Regarding the spot area, the most of studies described $0.028 \mathrm{~mm}^{2}$ spot area ${ }^{9-13,18,21-23}$.

\section{5) Energy density or Radiant exposure $\left(\mathrm{J} \cdot \mathrm{cm}^{-2}\right)$}

Different energy densities were employed in the studies analyzed, GaAlAs: $2.5 \mathrm{~J} \cdot \mathrm{cm}^{-216}, 3.5 \mathrm{~J} \cdot \mathrm{cm}^{-213}, 4$ $\mathrm{J} \cdot \mathrm{cm}^{-23,10} \mathrm{~J} \cdot \mathrm{cm}^{-215}, 30 \mathrm{~J} \cdot \mathrm{cm}^{-218}, 50 \mathrm{~J} \cdot \mathrm{cm}^{-222}, 100 \mathrm{~J} \cdot \mathrm{cm}^{-28,11}$, $120 \mathrm{~J} \cdot \mathrm{cm}^{-223}, 140 \mathrm{~J} \cdot \mathrm{cm}^{-211}, 210 \mathrm{~J} \cdot \mathrm{cm}^{-21} 2$ and $1000 \mathrm{~J} \cdot \mathrm{cm}^{-2} 10$; He-Ne:6 J.cm-219; InGaAlP: $3.5 \mathrm{~J} \cdot \mathrm{cm}^{-213}$ and $10 \mathrm{~J} \cdot \mathrm{cm}-215$. Two studies compared different protocols of energy densities, such as Atasoy et al., ${ }^{21}: 5 \mathrm{~J} \cdot \mathrm{cm}^{-2,} 10 \mathrm{~J} \cdot \mathrm{cm}^{-2}$ and $20 \mathrm{~J} \cdot \mathrm{cm}^{-2} ;$ Marques et al. ${ }^{20}: 3.7 \mathrm{~J} \cdot \mathrm{cm}^{-2}$ and $16 \mathrm{~J} \cdot \mathrm{cm}^{-2}$. The study of Tim et al., ${ }^{9}$ not described energy density.

\section{Laser intensity to modulation frequency $(\mathrm{MHz})$}

Only one laser study included in this review reported Laser intensity modulation frequency, whereby the authors report a modulation frequency of $1.5 \mathrm{MHz}^{22}$.

\section{7) Exposition time (time per point)}

The exposition time was refereed in some studies: 8 $\mathrm{s}^{18}, 10 \mathrm{~s}^{21}, 34 \mathrm{~s}^{23}, 40 \mathrm{~s}^{13}, 45 \mathrm{~s}^{16}$ temporal and quantitative evaluations are required to understand the healing process of large injuries. The aim of this study was to investigate the repair of critical-size bone defects in rat calvaria using a GaAlAs laser. Study Design/Materials and Methods Bone defects $\left(9 \mathrm{~mm}\right.$ in diameter, $47 \mathrm{~s}^{22}, 60$ $\mathrm{s}^{17,19}, 19,94 \mathrm{~s}^{8-10}, 120 \mathrm{~s}^{3,12}$. Two studies compared different exposition time: Marques et al., ${ }^{20} 3$ and $9 \mathrm{~s}$; Fernandes et al., ${ }^{11} 34$ and $60 \mathrm{~s}$. The study of Blaya et al., ${ }^{15}$ not described exposition time.

\section{8) Laser application schedule (days) and} treatment sessions

The daily schedule for PBM application for bone repair varied between 1 to 23 days for the studies addressed in this review. Some studies report PBM application on the alternate days of administration $3,9,10,12,13,15,17,18,20-23$. Some studies used only one evaluation period, totaling:5 sessions ${ }^{8-10}, 6$ sessions $^{3,21}$ and 8 sessions $^{15,17}$. Other studies have had two or more evaluation periods, such as: 6 and 18 sessions ${ }^{18 ;} 3$, 6 and 9 sessions $\mathrm{s}^{13} ; 3,6$ and 12 sessions ${ }^{14} 4,8$ and 11 sessions ${ }^{12} ; 2$ and 8 sessions $^{20} ; 8,15$ and 23 sessions ${ }^{23}$; $1,2,3$ and 5 sessions ${ }^{11} ; 6,20$ and 44 sessions ${ }^{19} ; 7,14$ and 28 sessions ${ }^{16}$ temporal and quantitative evaluations are required to understand the healing process of large injuries. The aim of this study was to investigate the repair of critical-size bone defects in rat calvaria using a GaAlAs laser. Study Design/Materials and Methods Bone defects $(9 \mathrm{~mm}$ in diameter. The number of PBM applications, type of analysis and results vary in the reported studies, according to Table 2.

\section{2) Animal models and defects}

Most studies used Wistar rats, only two studies employed rabbits ${ }^{3,19}$. Regarding animals sex, most of studies used male animals, one study used female animals ${ }^{21}$. There were no pig/sheep study models found within our inclusion criteria methods. Regarding defect localization, three different regions employed in the studies analyzed: calvaria $a^{3,16,18,20}$ constituting a promising strategy to produce bone tissue healing. Objective: the aim of the present study was to investigate the in vivo performance of PBM using an experimental model of cranial bone defect in rats. Material and Methods: rats were distributed in 2 different groups (control group and PBM group, femur $^{12,13}$ and tibia ${ }^{8-11,15,17,19,21-23}$. Different sizes of defects were created, most of this with circular design, with $1 \mathrm{~mm}^{19}, 2 \mathrm{~mm}^{15}, 2.5 \mathrm{~mm}^{11,13,22}, 3 \mathrm{~mm}^{8-10,23}, 5 \mathrm{~mm}^{18}, 6 \mathrm{~mm}^{3}, 8$ $\mathrm{mm}^{20}$ and $9 \mathrm{~mm}^{16}$ temporal and quantitative evaluations are required to understand the healing process of large injuries. The aim of this study was to investigate the repair of critical-size bone defects in rat calvaria using a GaAlAs laser. Study Design/Materials and Methods Bone defects $(9 \mathrm{~mm}$ in diameter. One study employed a rectangular defect $(5 \times 2 \mathrm{~mm})^{21}$. The animal and experimental model and the region of the bone that radiation was applied are described in Table 3.

\section{3) Biomodulation effects (analysis)}

To evaluate biomodulation effects were utilized several types of analysis, included: histopathological or histological analysis (in the most of

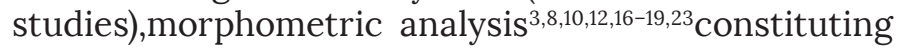
a promising strategy to produce bone tissue healing. Objective: the aim of the present study was to investigate the in vivo performance of PBM using an experimental 
Table 2. PBM application number, type of analysis and results

\begin{tabular}{|c|c|c|c|}
\hline Author & PBM application number & Analysis & Results \\
\hline $\begin{array}{l}\text { Magri et al., } \\
2019^{18}\end{array}$ & $\begin{array}{l}\text { Three applications per week } \\
\text { were performed, in non- } \\
\text { consecutive days, totalling } 6 \\
\text { and } 18 \text { sessions, respectively } \\
2 \text { and } 6 \text { weeks }\end{array}$ & $\begin{array}{l}\text { Histopathological, } \\
\text { histomorphometry and } \\
\text { immunohistochemistry } \\
\text { analysis }\end{array}$ & $\begin{array}{l}\text { Histology analysis demonstrated that for PBM most of the bone } \\
\text { defect was filled with newly formed bone (with a more mature } \\
\text { aspect when compared to CG). Histomorphometric analysis also } \\
\text { demonstrated a higher amount of newly formed bone deposition } \\
\text { in the irradiated animals, } 2 \text { weeks post-surgery. Furthermore, } \\
\text { there was a more intense deposition of collagen for PBM, } \\
\text { with ticker fibers. Results from Runx-2 immunohistochemistry } \\
\text { demonstrated that a higher immunostaining for CG } 2 \text { week's } \\
\text { post-surgery and no other difference was observed for Rank-L } \\
\text { immunostaining. }\end{array}$ \\
\hline $\begin{array}{l}\text { Atasoy et al., } \\
2017^{21}\end{array}$ & $\begin{array}{l}\text { Immediately, } 2,4,6,8,10 \\
\text { and } 12 \text { days postoperatively }\end{array}$ & $\begin{array}{l}\text { Histopathological } \\
\text { analysis }\end{array}$ & $\begin{array}{l}\text { This study showed that the application of } 940 \mathrm{~nm} \text { PBM with a } \\
\text { diode laser at different energy densities }\left(5 \mathrm{~J} \cdot \mathrm{cm}^{-2}, 10 \mathrm{~J} \cdot \mathrm{cm}^{-2} \text {, }\right. \\
\left.20 \mathrm{~J} \cdot \mathrm{cm}^{-2}\right) \text { may not accelerate the bone repair process in both } \\
\text { the initial and the late phases of healing in created defects } \\
\text { compared to the control. }\end{array}$ \\
\hline $\begin{array}{l}\text { Tim et al., } \\
2016^{8}\end{array}$ & $\begin{array}{l}\text { Laser irradiation started } \\
\text { immediately after the surgery } \\
\text { at one transcutaneous point, } \\
\text { above the site of the injury, } \\
\text { and it was performed with an } \\
\text { interval of } 24 \mathrm{~h} \text { between each } \\
\text { session, totaling five sessions }\end{array}$ & $\begin{array}{l}\text { Histopathological, } \\
\text { morphometry, } \\
\text { immunohistochemistry } \\
\text { andmicroarray analysis }\end{array}$ & $\begin{array}{l}\text { PBM was efficient in modulating the inflammatory process, } \\
\text { stimulating bone metabolism, and accelerating new bone } \\
\text { formation and collagen deposition at the site of the injury. Also, } \\
\text { PBM produced a significant increase in the expression of COL-I } \\
\text { expression, which contributes to the bone mineralization. This } \\
\text { fact may explain mechanisms that PBM acts on bone healing. } \\
\text { Therefore, these data highlight the potential of PBM to be used } \\
\text { as a therapeutic approach for bone regeneration. }\end{array}$ \\
\hline $\begin{array}{l}\text { Acar et al., } \\
2016^{3}\end{array}$ & $\begin{array}{l}24 \mathrm{~h} \text { after surgery, the animals } \\
\text { received PBM, three times a } \\
\text { week (every other day) for two } \\
\text { weeks (six sessions) }\end{array}$ & $\begin{array}{l}\text { Micro-CT, } \\
\text { histology and } \\
\text { histomorphometry } \\
\text { analysis }\end{array}$ & $\begin{array}{l}\text { PBM and LIPUS enhanced new bone formation in the third week } \\
\text { of your experiment. The optimal dose and duration of PBM and } \\
\text { LIPUS remain unknown, pending future investigation. }\end{array}$ \\
\hline $\begin{array}{l}\text { Tim et al., } \\
2016^{9}\end{array}$ & $\begin{array}{l}\text { PBM sessions were applied } \\
\text { immediately after the surgery } \\
\text { and repeated every } 24 \mathrm{~h} \text { at two, } \\
\text { three and seven days }\end{array}$ & $\begin{array}{l}\text { Histopathological, } \\
\text { microarray, and } \\
\text { immunohistochemistry } \\
\text { analysis }\end{array}$ & $\begin{array}{l}\text { PBM was efficient in modulating the inflammatory process and } \\
\text { increasing the newly formed bone. In addition, PBM produced } \\
\text { a significant increase in the expression of genes related to } \\
\text { inflammation and angiogenesis. This fact may explain some of } \\
\text { the molecular pathways by which PBM acts on the stimulation } \\
\text { of bone tissue during the healing process and results in the } \\
\text { earlier resolution of the inflammatory process and earlier } \\
\text { differentiation of pre osteoblastic cells into mature osteoblasts, } \\
\text { thus accelerating the bone healing process. }\end{array}$ \\
\hline $\begin{array}{l}\text { Tim et al., } \\
2015^{10}\end{array}$ & $\begin{array}{l}\text { Laser irradiation started } \\
\text { immediately after the bone } \\
\text { defect procedure and it was } \\
\text { performed with an interval of } \\
24 \mathrm{~h} \text { between each session, they } \\
\text { have received one, two, three, } \\
\text { five, and seven sessions of PBM, } \\
\text { respectively }\end{array}$ & $\begin{array}{l}\text { Histopathological, } \\
\text { morphometry and } \\
\text { microarray analysis }\end{array}$ & $\begin{array}{l}\text { PBM improved bone healing by producing a significant increase } \\
\text { in the expression of osteogenic genes. Consequently, these data } \\
\text { highlight the potential of the use of this therapy to improve } \\
\text { the biological performance of bone regeneration applications. } \\
\text { Further, long-term studies should be carried out to provide } \\
\text { additional information concerning the late stages of the } \\
\text { interaction between PBM and bone healing process. }\end{array}$ \\
\hline $\begin{array}{l}\text { Batista et al., } \\
2015^{12}\end{array}$ & $\begin{array}{l}\text { In the postoperative period, } \\
\text { applications were taken } \\
\text { every } 48 \text { h for } 7,15 \text {, and } 21 \\
\text { days, resulting in } 4,8 \text {, and } 11 \\
\text { sessions, according to each } \\
\text { subgroup }\end{array}$ & $\begin{array}{l}\text { Histologic and } \\
\text { histomorphometric } \\
\text { analysis }\end{array}$ & $\begin{array}{l}\text { PBM exerts a biostimulatory effect and may be helpful in } \\
\text { improving bone healing after surgical procedures. However, the } \\
\text { results did not demonstrate any changes in bone repair after } \\
\text { the application of PBM a long distance from the evaluated area. }\end{array}$ \\
\hline
\end{tabular}




\begin{tabular}{|c|c|c|c|}
\hline $\begin{array}{l}\text { Marques et al., } \\
2014^{20}\end{array}$ & $\begin{array}{l}\text { Protocol 1: Applications every } \\
48 \mathrm{~h} \text { starting } 24 \mathrm{~h} \text { after surgery, } \\
\text { extending for } 15 \text { days. } \\
\text { Protocol } 2 \text { : One application } \\
\text { during the procedure, followed } \\
\text { by two transcutaneous } \\
\text { applications } 48 \text { and } 96 \text { hours } \\
\text { after surgery }\end{array}$ & $\begin{array}{l}\text { Microscopic and } \\
\text { immunohistochemistry } \\
\text { analysis }\end{array}$ & $\begin{array}{l}\text { PBM is a valuable technique presenting the ability to accelerate } \\
\text { bone regeneration. The protocol presented in this work } \\
\text { demonstrates that PBM works in the early stages of the bone } \\
\text { regeneration process. }\end{array}$ \\
\hline $\begin{array}{l}\text { Tim et al, } \\
2014^{23}\end{array}$ & $\begin{array}{l}\text { Immediately after the surgery } \\
\text { and repeated every } 48 \mathrm{~h} \text {, in a } \\
\text { total of } 8,15 \text {, and } 23 \text { sessions, } \\
\text { depending on the period of } \\
\text { sacrifice }\end{array}$ & $\begin{array}{l}\text { Histopathological, } \\
\text { morphometry, } \\
\text { immunohistochemistry } \\
\text { and biomechanical } \\
\text { analysis }\end{array}$ & $\begin{array}{l}\text { The laser therapy improved bone healing process by accelerating } \\
\text { the deposition and organization of newly formed bone and } \\
\text { activating osteogenic factors as RUNX-2 and BMP-9 on created } \\
\text { bone defects in tibias of rats. }\end{array}$ \\
\hline $\begin{array}{l}\text { de Oliveira et } \\
\text { al, } 2014^{16}\end{array}$ & $\begin{array}{l}\text { The irradiation protocol began } \\
\text { afterwards the surgery and } \\
\text { followed six times more at } \\
\text { 48hours intervals, depending } \\
\text { on the period of sacrifice }\end{array}$ & $\begin{array}{l}\text { X-ray, Histological and } \\
\text { Histomorphometric } \\
\text { analýsis }\end{array}$ & $\begin{array}{l}\text { The use of low-level laser therapy is safe and does not cause } \\
\text { tissue pathologic changes. LLLT using 830nm wavelength } \\
\text { promotes the acceleration and increase of bone repair and } \\
\text { the development of more mature bone tissue than the control } \\
\text { group. }\end{array}$ \\
\hline $\begin{array}{l}\text { Fernandes } \\
\text { et al, } 2013^{11}\end{array}$ & $\begin{array}{l}\text { The treatments, which started } \\
\text { immediately post-surgery, were } \\
\text { performed for one ( } 12 \mathrm{~h}) \text {, two } \\
(36 \mathrm{~h}) \text {, three }(3 \mathrm{~d}) \text { or five }(5 \mathrm{~d}) \\
\text { sessions, with an interval of } \\
24 \mathrm{~h}\end{array}$ & $\begin{array}{l}\text { Histopathological, } \\
\text { Total RNA Isolation } \\
\text { and Real time PCR } \\
\text { analysis }\end{array}$ & $\begin{array}{l}\text { PBM evoked an earlier resolution of the inflammatory process } \\
\text { and new bone formation. Also, PBM produced a significant } \\
\text { increase in mRNA expression of Runx-2, ALP and OC, which are } \\
\text { involved in bone repair. Despite these results, further studies } \\
\text { are required to investigate the mechanisms and molecular } \\
\text { pathways stimulated by PBM that culminate in the acceleration } \\
\text { of bone healing. }\end{array}$ \\
\hline $\begin{array}{l}\text { Peccin et al, } \\
2013^{9}\end{array}$ & $\begin{array}{l}\text { The treatments started at } \\
24 \mathrm{~h} \text { postsurgery and were } \\
\text { performed daily, for } 1,3 \text {, and } 5 \\
\text { weeks }\end{array}$ & $\begin{array}{l}\text { Histopathological and } \\
\text { morphometric analysis }\end{array}$ & $\begin{array}{l}\text { He-Ne laser is able to improve bone repair in rabbits being the } \\
\text { most pronounced effect in tibia. }\end{array}$ \\
\hline $\begin{array}{l}\text { Barbosa et al, } \\
2013^{31}\end{array}$ & $\begin{array}{l}\text { Immediately after osteotomy } \\
\text { and repeated every } 48 \text { h on the } \\
\text { same days, three times a week, } \\
\text { during the experimental times } \\
\text { of } 7 \text { days (three sessions), } 14 \\
\text { days (six sessions), and } 21 \text { days } \\
\text { (nine sessions) }\end{array}$ & $\begin{array}{l}\text { Optical densitometry } \\
\text { analysis }\end{array}$ & $\begin{array}{l}\text { PBM accelerates bone repair in the initial phase independent } \\
\text { of the wavelength used, and this effect remains for } 14 \text { days } \\
\text { when using an infrared laser. Therefore, it is concluded that PBM } \\
\text { induced a biomodulatory positive effect on the healing process } \\
\text { of bone defects, which was time- and wavelength-dependent. } \\
\text { Also, our results have confirmed that optical densitometry } \\
\text { technique can measure bone mineralization status. }\end{array}$ \\
\hline $\begin{array}{l}\text { Fávaro-Pípi } \\
\text { et al. } 2010^{22}\end{array}$ & $\begin{array}{l}\text { The treatments started } 24 \\
\text { h post-surgery and were } \\
\text { performed for } 3,6 \text {, and } 12 \\
\text { sessions, with an interval of } \\
48 \mathrm{~h} \text {. }\end{array}$ & Histological analysis & $\begin{array}{l}\text { The present study has demonstrated the positive effects of } \\
\text { PBM on bone repair as depicted by histopathological and } \\
\text { morphometric analysis, mainly at intermediary ( } 13 \text { days) and } \\
\text { late periods ( } 25 \text { days) after bone injury. Conversely, treatment } \\
\text { with LIPUS, in the regime used in this work, did not have any } \\
\text { effect on bone healing at any period evaluated post-injury. } \\
\text { Despite these results, further investigations are required to } \\
\text { study the possible response mechanisms that may explain } \\
\text { the positive effects of the PBM on bone tissue. Such future } \\
\text { studies will undoubtedly contribute to a better understanding } \\
\text { of the safety of laser therapy and the design of future research } \\
\text { strategies using human experiments }\end{array}$ \\
\hline $\begin{array}{l}\text { Matsumoto } \\
\text { et al., } 2009^{17}\end{array}$ & $\begin{array}{l}\text { Immediately after the end of } \\
\text { surgery and at each } 48 \text { hours } \\
\text { (eight applications on the } 15^{\text {th }} \\
\text { day) }\end{array}$ & Histologic study & $\begin{array}{l}\text { This study showed eight red or infrared laser applications (10)/ } \\
\mathrm{cm} 2 \text { ) significantly increased bone formation and the degree } \\
\text { of vertical bone regeneration. It did not affect the degree of } \\
\text { cortical bone formation in the animal model studied }\end{array}$ \\
\hline $\begin{array}{l}\text { Blaya et al., } \\
2008^{15}\end{array}$ & $\begin{array}{l}\text { Laser irradiation was initiated } \\
24 \mathrm{~h} \text { after the surgery and was } \\
\text { performed, punctually, every } \\
48 \mathrm{~h} \text { for } 15 \text { days, or until the rat } \\
\text { was killed }\end{array}$ & $\begin{array}{l}\text { Histopathological, } \\
\text { morphometry and } \\
\text { immunohistochemistry } \\
\text { analysis }\end{array}$ & $\begin{array}{l}\text { Low-level laser therapy is able to improve bone repair in the tibia } \\
\text { of rats after } 14 \text { days of surgery as a result of an up-regulation for } \\
\text { cyclo-oxygenase-2 expression. }\end{array}$ \\
\hline
\end{tabular}


Table 3. Data from included studies regarding animal and experimental model, a region of radiation and results

\begin{tabular}{|c|c|c|c|}
\hline Author & Animal & Experimental Model & Region of the radiation \\
\hline Magri et al., $2019^{18}$ & Wistar rats & Calvaria bone defects ( $5 \mathrm{~mm})$ & Defect area \\
\hline Atasoy et al., $2017^{21}$ & Wistar rats & Tibial bone defect rectangular $5 \times 2 \mathrm{~mm}$ & Tibia \\
\hline Tim et al., $2016^{8}$ & Wistar rats & Bilateral tibial bone defect $(3 \mathrm{~mm})$ & Defect area \\
\hline Acar et al., $2016^{3}$ & $\begin{array}{l}\text { New Zealand } \\
\text { white rabbits }\end{array}$ & Bilateral calvaria bone defects $(6 \mathrm{~mm})$ & Defect area \\
\hline Tim et al., $2016^{9}$ & Wistar rats & Bilateral tibial bone defect $(3 \mathrm{~mm})$ & Tibia \\
\hline Tim et al., $2015^{10}$ & Wistar rats & Tibial bone defect ( $3 \mathrm{~mm})$ & Upper third of the tibia \\
\hline Batista et al., $2015^{12}$ & Wistar rats & Femoral bone defect $(2-3 \mathrm{~mm})$ & Left femur \\
\hline Marques et al., $2014^{20}$ & Wistar rats & Calvaria bone defect $(8 \mathrm{~mm})$ & Defect area \\
\hline Tim et al, $2014^{23}$ & Wistar rats & Bilateral tibial bone defect $(3 \mathrm{~mm})$ & Defect area \\
\hline de Oliveira et al, $2014^{16}$ & Wistar rats & Calvaria bone defect $(9 \mathrm{~mm})$ & Defect area \\
\hline Fernandes et al, $2013^{11}$ & Wistar rats & Tibial bone defect $(2.5 \mathrm{~mm})$ & Defect area \\
\hline Peccin et al, $2013^{19}$ & $\begin{array}{l}\text { New Zealand } \\
\text { rabbits }\end{array}$ & $\begin{array}{l}\text { Tibial bone defect ( } 1 \mathrm{~mm} \text { diameter } \times 2 \\
\mathrm{~mm} \text { depth) }\end{array}$ & Defect area \\
\hline Barbosa et al, $2013^{31}$ & Wistar rats & Femoral bone defect $(2.5 \mathrm{~mm})$ & The right femoral region of the animals \\
\hline $\begin{array}{l}\text { Fávaro-Pípi et al. } \\
2010^{22}\end{array}$ & Wistar rats & Tibial bone defect ( $2.5 \mathrm{~mm}$ diameter) & $\begin{array}{l}\text { At the upper third of the tibia ( } 10 \mathrm{~mm} \text { distal of the knee } \\
\text { joint). }\end{array}$ \\
\hline $\begin{array}{l}\text { Matsumoto et al., } \\
2009^{17}\end{array}$ & Wistar rats & Tibial bone defect (2 mm) & Defect area \\
\hline Blaya et al., $2008^{15}$ & Wistar rats & Tibial bone defect (5 mm deep) & $\begin{array}{l}\text { Transcutaneously, at one point, above the lesion on the } \\
\text { injured tibias }\end{array}$ \\
\hline
\end{tabular}

model of cranial bone defect in rats. Material and Methods: rats were distributed in 2 different groups (control group and PBM group immunohistochemistry analysis $\mathrm{s}^{8,9,17,18,20,23}$, microarray analysis ${ }^{8-10}$, micro-CT analysis ${ }^{3}$, biomechanical analysis ${ }^{23}, \mathrm{PCR}^{11}$ and X-ray analysis ${ }^{16}$ temporal and quantitative evaluations are required to understand the healing process of large injuries. The aim of this study was to investigate the repair of critical-size bone defects in rat calvaria using a GaAlAs laser. Study Design/Materials and Methods Bone defects $(9 \mathrm{~mm}$ in diameter. One study employed just optical densitometry ${ }^{13}$.

\section{Discussion}

\section{Bone repair}

Bone is an important anatomical structure, as it provides movement and structural support, in addition to performing biological functions linked to mineral balance and production of defense cells ${ }^{24}$.

The bone tissue formation is related to two processes: formation of primary bone tissue, related to fetal development; and the bone repair process. This tissue is organized in trabeculae, where the osteoblasts producing the trabecular bone matrix are found. The tissue is rich in osteocytes and bundles of collagen arranged irregularly, without dominant orientation. These unshaped collagen bundles are subsequently replaced and organized as secondary bone ${ }^{2}$.
The secondary bone tissue represents the mature bone, formed by the same components of the primary tissue. The main characteristic of this tissue is the presence of collagen fibers organized in lamellae, parallel to each other in a very peculiar arrangement. These lamellae, when arranged in concentric layers around canals with vessels, constitute the Havers systems, which is typical of secondary bone tissue. The Havers systems communicate with each other, with the spinal canal and with the bone surface through transverse or oblique channels, called Volkmann channels ${ }^{25}$.

Bone fractures are injuries common to the human body, with the tibia being the most affected bone, with poor healing due to non-union of the fractured parts $^{26}$. The fracture repair process occurs in several stages similarly to the bone formation process that occurred during embryogenesis, starts with a local response and ends with the recovery of mechanical properties $^{27,28}$. Although the bone tissue is capable of self-healing, fractures and critical defects can suffer with healing difficulties, due to inadequate irrigation conditions and the non-union between the fractured $\operatorname{parts}^{29,30}$.

In the last years, the area of biology of bone repair has studied several therapeutic strategies that help bone repair, contributing significantly to regenerative medicine. Several efforts have focused on accelerating 
the process of healing bone fractures, reducing the length of the recovery process and improving the quality of life ${ }^{31}$. New therapies have been investigated to increase bone metabolism and repair ${ }^{32}$, including PBM therapy. The use of lasers has been shown to be efficient in resolving the inflammatory process after injury, improving vascularization and consequently reducing bone healing time, having a beneficial effect on the metabolism and fracture healing ${ }^{4,33}$.

\section{Bone repair and Photobiomodulation}

Theodore Maiman introduced the use of lasers, equipment capable of producing non-ionizing electromagnetic radiation. In biological applications, lasers should not cause iatrogenic tissue damage ${ }^{34,35}$. Thus, PBM or LLLT therapy is used to stimulate tissues and cells by non-thermal means ${ }^{36}$. The first results in this field of work began with Pr. Mester, who in 1967 reported the use of lasers and their relationship with hair growth in $\operatorname{rats}^{37}$. Unlike other light sources, the laser has properties with monochromatic light, coherence and collimation $^{38}$. The laser equipment emits light through optical amplification, emitting photons. Laser light is still considered to have high spatial and temporal coherence ${ }^{39}$.

In vivo ${ }^{22}$ and in vitro ${ }^{40}$ studies have demonstrated the effects of PBM therapy on bone cells, showing that it promotes regulation of various growth factors, expression, protein and genes linked to bone cell differentiation, promoting osteoblast proliferation and activity ${ }^{14,41}$. However, the mechanism of PBMfunctioning in bone tissue is not completely understood, and its use as therapy can be considered contestable ${ }^{42}$ however. The effects of wavelength, beam type, energy output, energy level, energy intensity, and exposure regime of low level laser therapy remain unexplained. Moreover, no specific therapeutic window for dosimetry and mechanism of action has been determined at the level of individual cell types. The aim of this study was to investigate the effects of low level laser irradiation on the human osteosarcoma cell line, SAOS-2. The cells were irradiated as a single or daily dose for up to 10 days with a GaAlAs continuous wave diode laser $(830$ $\mathrm{nm}$, net output of $90 \mathrm{~mW}$, energy levels of $0.3,0.5,1$, 2 , and 4 Joules. PBM therapy uses light to accelerate the resolution of the inflammatory process and, consequently, improve tissue repair and decrease pain $^{43}$. The technique was called "low intensity" because the energy used is less than that used for ablation, cutting and thermal coagulation procedures of tissues ${ }^{44}$.

After the light reaches the tissue, absorption of one part occurs and reflection or dispersion of another, and depending on the thickness of the tissue, light transmission can occur, a phenomenon called absorption, capable of promoting the beneficial effects to the tissue ${ }^{39}$. Absorption causes three primary effects: biochemical, bioelectric and bioenergetics. These effects, in turn, will give rise to other physiological effects with greater depth and extension considered as secondary effects stimulation of the microcirculation and increased local trophic, which increases the repair processes. Thus, it is noted that the bone repair is determined by the local trophic and that the increase of the mitotic velocity is responsible for the increase of the speed of bone repair ${ }^{34}$.

High irradiances reported in the literature are commonly due to small irradiation spot size, often derived from the aperture of the laser. However, calculating the irradiance when the spot-size is much smaller than the wavelength's penetration depth, the photon distribution is not following a 1-dimensional distribution but follows a hemispherical distribution pattern. Hence, for PBM based on small spot sizes, authors should report only power, exposure time and time.

The studies selected for this review show the effect of PBM therapy on bone regeneration, both in resolving the inflammatory process and in repair. Regarding the anti-inflammatory effect of PBM therapy, GaAlAs at $\mathrm{J} \cdot \mathrm{cm}^{-}$was able to improve bone repair in the tibia of rats 14 days after the surgical procedure, alerting to a positive relationship of the PBM and the resolution of the inflammatory process ${ }^{17}$. The study by Atasoy et al. $^{21}$ analyzed the effect of PBM therapy with a wavelength of $940 \mathrm{~nm}$ and energy intensities of 5, 10 and $20 \mathrm{~J} \cdot \mathrm{cm}^{-2}$ for this, bone defects were created in the right tibia of female rats. PBM with the $10 \mathrm{~J} \cdot \mathrm{cm}^{-2}$ energy density increased fibroblast activity in the 4 th week in comparison with the 5 and $20 \mathrm{~J} \cdot \mathrm{cm}^{-2}$ groups. Likewise, Peccin et al. ${ }^{19}$ evaluated the effect of the helium-neon laser on bone repair of the femur and tibia in rabbits. After three weeks, the laser group had new bone formation in both the femur and tibia. In the 5th week, remodeling in a more intense pattern in the tibia was observed.

In the study of Batista et al. ${ }^{12}$, osteotomy was performed in the left femur of rats. The PBM produced a positive local biostimulation effect (bone remodeling) in the early stage of bone healing, although the PBM effect was not observed at a longer distance from the irradiated area. Based on the degree of bone mineralization in a rat model, Barbosa et al. ${ }^{13}$ showed that the positive bone repair effect of PBM is timeand wavelength-dependent. The authors founded a significant difference after red (660-690 nm) and in the infrared (790-830 $\mathrm{nm}$ ) irradiation after seven days of the bone defect. After 14 days, only the group treated with infrared PBM showed higher bone density. At 21 days, there was no statistical difference between the 
PBM treated groups and the control.

Tim et al. ${ }^{9}$ also using a rat model of tibia defect and laser treatment $(830 \mathrm{~nm}, 30 \mathrm{~mW}, 2.8 \mathrm{~J}, 94 \mathrm{sec})$, found that PBM was able to improve bone neoformation, modulating the inflammatory process, and angiogenic gene expression during the initial phase of bone healing. The same parameters of laser therapy were used to evaluate microarray analysis in a rat tibia defect model. In another study (Tim et al., 2014) ${ }^{23}$ denoted an important increase in the expression of TGF- $\beta$, BMP, FGF, and RUNX-2, evidencing a possible relationship between the proliferation and differentiation of osteoblasts through PBM therapy. Acar et al. (3), investigated the effects of $\mathrm{PBM}$ and ultrasound on bone repair in rabbits. Both methods promoted bone formation in the initial stage of healing (three weeks after surgery), but the combination of both did not promote better results.

Although PBM therapy results seem to be encouraging for its use in preclinical studies with possible extrapolation for the therapeutic use in humans, it is noted that researchers employ different laser parameters. This fact can be considered as one of the main gaps to be filled in the coming years. This theory is confirmed by recent systematic reviews that analyzed the effects of PBM therapy on bone repair, even though these studies included studies involving the use of biomaterials, systemic conditions or even bone grafts ${ }^{45,46}$.

\section{Bone defects and experimental designs}

In vivo studies frequently are used when aiming to study bone repair. Animal models are largely used, as they are able to provide important information about the repair conditions in a given tissue, allowing to investigate new drugs, devices, biomaterials and therapeutic strategies. Especially in the bone repair biology field, it is possible to verify evidence of physiological or pathological ossification ${ }^{47,48}$. The purpose of these studies is to provide sufficient knowledge for future clinical studies involving bone regeneration. Therefore, the use of critical bone defects is the most adequate experimental model for this purpose. Critical bone defects is the denomination given to the smallest intraosseous defect that does not spontaneously regenerate during the animal's life $^{49}$.

Several studies use calvaria as an experimental model in bone regeneration, as it is considered anatomically similar to the jaw because it consists of a layer of medullary bone surrounded by two cortical bones, being an effective way to simulate therapeutic effects in craniofacial defects ${ }^{48,49}$. In addition, the dura-mater is identified as a source of mesenchymal cells that participate in the process of repairing the cavity $^{50,51}$. Regarding to surgical aspects, the calvaria stands out for presenting a satisfactory visual field for the realization of surgical access and intraoperative management, in the postoperative period the dura mater and the subcutaneous layer provide physical support for the repair process. However, there a some disadvantages of this model, such as the impossibility of analyzing the response of bone tissue to biomechanical loads $^{48}$. The dura mater injury can lead to impairment of the healing process, due the function of being the main osteogenic cells and osteoinductive substances source ${ }^{52}$. Considering the defects, these are performed with a surgical trephine bur, the length of which can vary from 5 to $8 \mathrm{~mm}$ in diameter, extending into the two bone cortical - central defect ${ }^{53-56}$. Still regarding size, there is no consensus in the literature as to the ideal size, however there is a tendency for the creation of central defects with a diameter of 5-8 $\mathrm{mm}^{47-49,57,58}$. The surgical procedure on calvaria must be careful, in order to create defects with small depth, so as not to cause damage to the meninges which can lead to animal death. Studies involving repair of critical defects in calvaria are preferably performed in rats, due to the advantages that this animal model represents.

This review founded the use of critical defects in rats and rabbits calvaria. Regarding bone defects in rats, the study of Magri et al., ${ }^{18}$ used defects of $5 \mathrm{~mm}$, in contrast to the study of Marques et al., ${ }^{20}$ in which defects of $8 \mathrm{~mm}$ used and de Oliveira et al, ${ }^{16}$ temporal and quantitative evaluations are required to understand the healing process of large injuries. The aim of this study was to investigate the repair of critical-size bone defects in rat calvaria using a GaAlAs laser. Study Design/Materials and Methods Bone defects $(9 \mathrm{~mm}$ in diameter used $9 \mathrm{~mm}$ bone defect. The study of Acar et al, ${ }^{3}$ used rabbits with two $6 \mathrm{~mm}$ bone defects. The use of two bone defects for calvaria allows a decrease in the number of animals, and can be used in studies with rats ${ }^{59}$.

In addition to bone defects created in rat and rabbit calvaria, most studies analyzed by this review used bone defects created in long bones, mainly tibia $^{8-11,14,15,17,19,23}$ and femur ${ }^{12,31}$. Surgical access to long bones such as the tibia and femur is relatively more difficult to perform when compared to access to the calvaria. The size of the defects created is substantially smaller in long bones, comprising studies evaluated between $2-3 \mathrm{~mm}$, however the depth of the defect is greater than that of the defects of calvaria. Regarding to the repair process, the repair of the calvaria occurs by intramembranous ossification, while in tibial and femoral defects, the repair occurs by the endochondral process which is associated with higher repair rates in this sites ${ }^{60}$. The healing of long bones is considered up to twice as fast as that of flat bones, a process allied to the presence of the periosteum of the tibia or femur 
and high vascularization ${ }^{58}$. Another factor associated with faster bone regeneration in long bones appears to be the mechanical load associated with the animal's movement, unlike calvaria ${ }^{61}$. Mechanical tension can be considered an important factor that regulates the formation and renewal of bone tissue ${ }^{62}$. The lack of mechanical load can cause a reduction of matrix proteins ${ }^{63,64}$. The stress caused by mechanical efforts leads to the expression of osteoblast differentiation markers, such as OPN, Runx2, COLI and ALP62.

\section{Animals used for experimentation}

Of the studies analyzed, 14 indicated the use of rodents (Wistar rats), which shows a predilection for this animal model, creating defects generally in the tibia, femur or calvaria. The rats use in bone regeneration studies has several advantages, as they are considered low cost animals, easy to allocate and easy to handle ${ }^{65}$. Sedation procedures are efficient and easy to perform. Another point its considerably rapid skeletal maturity, understood in a maximum of 7 months ${ }^{66}$. These animals are widely used on calvaria bone healing studies, as well as in long bones, even though this bones are small in size, with thin and fragile cortical bone, in addition to not having Haversian remodeling in the cortex, in contrast to larger animals ${ }^{67,68}$.

The use of rabbits in experimental research is quite frequent, as they have similarities in the mineral density of bone tissue and fracture toughness when compared to humans. In addition, its bone-renewing properties are rapid, due to its accelerated metabolism. In addition, they are considered calm and easy to handle animals ${ }^{69,70}$ joints and soft tissues has been enhanced by the use of experimental animal models. Articles reporting on the results of these biomedical experiments frequently include conclusions that are based on the assumption that the biology of the animal model is similar to that of a human being for the disease process under investigation. The purpose of this investigation was to study the criteria and the considerations for selection of an animal model in musculoskeletal research. Selected journals from the musculoskeletal literature published between January 1991 and November 1995 were scrutinized for the use of animal models, and several criteria used in the selection of the various animal models were investigated. The selection criteria analyzed in this study included the biologic characteristics of the model, budget issues, the reproducibility of a musculoskeletal disease, and animal handling factors. A computer-assisted search of the musculoskeletal literature published from 1965 to 1995 was also performed to screen for reports comparing mammals used as animal models in terms of these selection criteria. Our findings imply that the selection of animal models in research of the musculoskeletal system is based partly on non-standardized criteria that are not necessarily based on the biology of the disease process being studied. In addition, there are limited comparative data on the selection and use of different animals for musculoskeletal research. We believe the selection of models should be more standardized based on both biological and non-biological criteria. Researchers would then be able to put in a more meaningful perspective the results of research using animal models and their clinical implications. involving bone repair, and the most studied sites are their tibias, femurs and calvaria.

Pigs are representative animal models that are very close to human bone repair processes ${ }^{71,72}$. The diameter and sectional area of the femur and its lamellar structure are similar to that of humans ${ }^{73,74}$. Its trabecular network is more dense, difficult to handle, and this aspect disadvantages its use as an animal model, and among larger animals, sheep and goats are preferred $^{74-76}$. The length of tibiae and femurs in pigs is shorter, another point that creates a disadvantage.

The long bones of sheep are often used to test implants on human prostheses, which is not possible with rabbits and pigs for example. In the microscopic aspect, the bone of sheep has a higher trabecular density than that of humans. However, these differences may change depending on the location. Sheep are considered to be an applicable model, however differences with human bone tissue should be considered, for example, in the amount of spongy bone in the distal femur ${ }^{77-80}$.

Studies with rabbits are a safe model, but still little explored in the literature. The use of larger animals such as pigs and especially sheep, despite having higher costs, can be an important step to promote a greater understanding of the repair of these tissues using PBM, since their similarity to human structures is greater (Fig. 2).

Through this review it was possible to observe that PBM therapy promotes encouraging results, even though the laser parameters have varied considerably. A tendency was observed for the use of small animals for these studies, preferably rodents, where most of them were used tibial defects, with small diameter. To date, most studies conducted in vivo using PBM therapy in bone tissue are qualitative, whereas to establish their bone remodeling effectiveness, quantitative studies should be performed. Therefore, we suggest that the use of small animals with tibial defects can be considered as a valid model to assess the effects of PBM therapy, without disregarding the importance of the calvarial defect model. Future pre-clinical studies should focus on the definition of a universal parameter and on the use of experimental models with larger animals. 


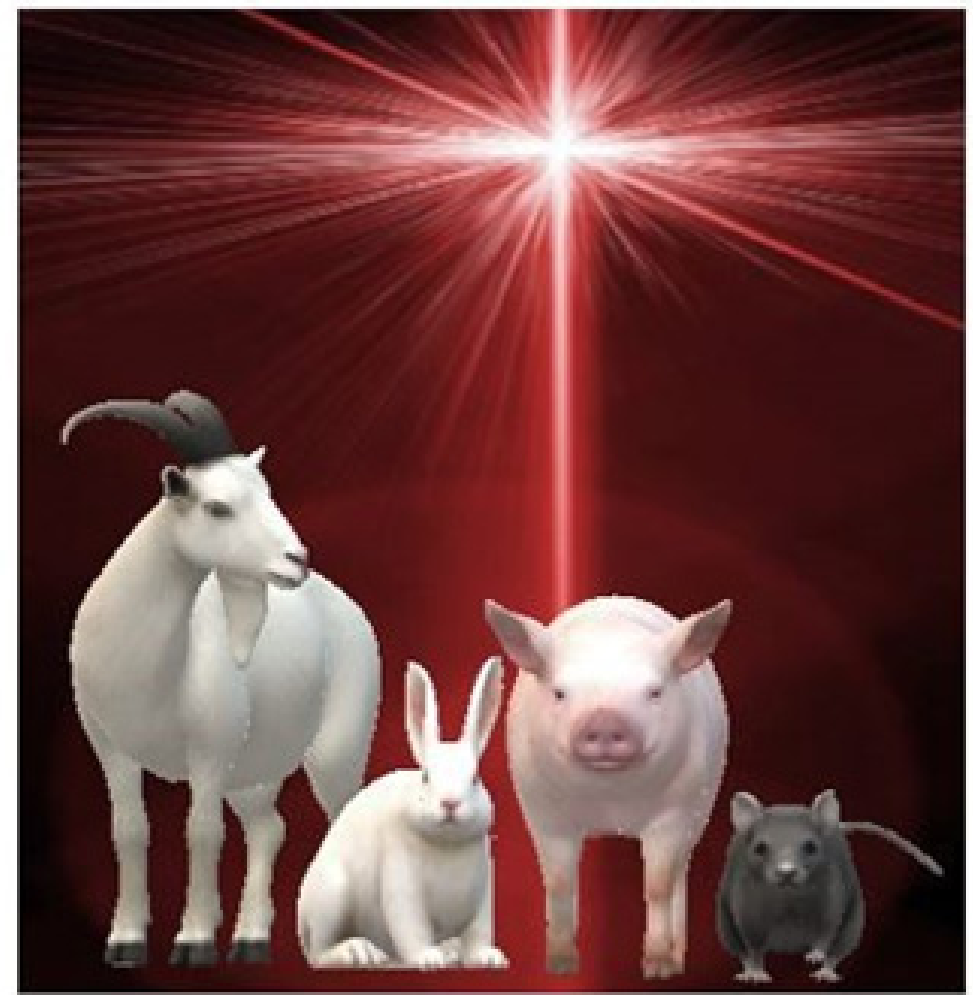

Animal models
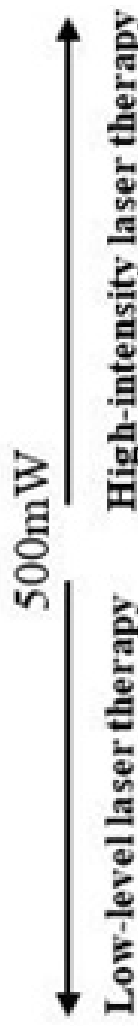

Ablative or thermal mechanism; Cutting and tissue coagulation; Effects in deep tissues; Increase cell metabolism, vascular permeability and blood flow;
Non- thermal mechanism;

Light is absorbed;

Tissue regeneration;

Reduce inflammation and edema;

Prevent tissue damage;

Relieve pain.

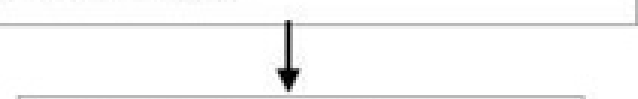

\section{Region of radiation: \\ Tibial bone; Calvarial bone, Femoral bone; Femur.}

Figure 2. Animal models, low-level and high-intensity laser therapy and region of radiation

\section{References}

1. Giannoudis P V., Dinopoulos H, Tsiridis E. Bone substitutes: An update. Injury [Internet]. 2005 Nov;36(3):S20-7.

2. Gartner F, Hiatt J. Color Textbook of Histology. 3rd ed. Philadelphia: Saunders; 2007.

3. Acar AH, Yolcu Ü, Altındiş S, Gül M, Alan H, Malkoç S. Bone regeneration by low-level laser therapy and low-intensity pulsed ultrasound therapy in the rabbit calvarium. Arch Oral Biol [Internet]. 2016 Jan;61:60-5.

4. Kazem Shakouri S, Soleimanpour J, Salekzamani Y, Oskuie MR. Effect of low-level laser therapy on the fracture healing process. Lasers Med Sci [Internet]. 2010 Jan 28;25(1):73-7.

5. Li Y, Chen SK, Li L, Qin L, Wang XL, Lai YX. Bone defect animal models for testing efficacy of bone substitute biomaterials. J Orthop Transl. 2015;3(3):95-104.

6. Bashardoust Tajali S, MacDermid JC, Houghton P, Grewal R. Effects of low power laser irradiation on bone healing in animals: a metaanalysis. J Orthop Surg Res [Internet]. 2010 Dec 4;5(1):1.

7. Pires-Oliveira DAA, Oliveira RF, Amadei SU, Pacheco-Soares C, Rocha RF. Laser $904 \mathrm{~nm}$ action on bone repair in rats with osteoporosis. Osteoporos Int. 2010;21(12):2109-14.

8. Tim CR, Bossini PS, Kido HW, Malavazi I, von Zeska Kress MR, Carazzolle MF, et al. Low-level laser therapy induces an upregulation of collagen gene expression during the initial process of bone healing: a microarray analysis. J Biomed Opt [Internet]. 2016 Aug 19;21(8):088001.

9. Tim CR, Bossini PS, Kido HW, Malavazi I, von Zeska Kress MR, Carazzolle MF, et al. Effects of low level laser therapy on inflammatory and angiogenic gene expression during the process of bone healing: A microarray analysis. J Photochem Photobiol B Biol [Internet]. 2016 Jan;154:8-15.

10. Tim CR, Bossini PS, Kido HW, Malavazi I, von Zeska Kress MR, Carazzolle MF, et al. Effects of low-level laser therapy on the expression of osteogenic genes during the initial stages of bone healing in rats: a microarray analysis. Lasers Med Sci [Internet]. 2015 Dec 28;30(9):2325-33.

11. Fernandes KR, Ribeiro DA, Rodrigues NC, Tim C, Santos AA, Parizotto $N A$, et al. Effects of low-level laser therapy on the expression of osteogenic genes related in the initial stages of bone defects in rats. J Biomed Opt [Internet]. 2013 Mar 20;18(3):038002.

12. Batista JD, Sargenti-Neto S, Dechichi P, Rocha FS, Pagnoncelli RM. Low-level laser therapy on bone repair: is there any effect outside the irradiated field? Lasers Med Sci [Internet]. 2015 Jul 15;30(5):1569-74. 13. Barbosa D, de Souza RA, Xavier M, da Silva FF, Arisawa EÂL, Villaverde AGJB. Effects of low-level laser therapy (LLLT) on bone repair in rats: optical densitometry analysis. Lasers Med Sci [Internet]. 2013 Feb 6;28(2):651-6.

14. Fávaro-Pípi E, Ribeiro DA, Ribeiro JU, Bossini P, Oliveira P, Parizotto $\mathrm{NA}$, et al. Low-level laser therapy induces differential expression of osteogenic genes during bone repair in rats. Photomed Laser Surg. 2011;29(5):311-7.

15. Blaya DS, Guimarães MB, Pozza DH, Weber JBB, de Oliveira MG. Histologic study of the effect of laser therapy on bone repair. J Contemp Dent Pract [Internet]. 2008 Sep 1;9(6):41-8.

16. De Oliveira AM, Castro-Silva II, De Oliveira Fernandes GV, Melo BR, Alves ATNN, Silva Júnior A, et al. Effectiveness and acceleration of bone repair in critical-sized rat calvarial defects using low-level laser therapy. Lasers Surg Med. 2014;46(1):61-7.

17. Matsumoto MA, Ferino R V., Monteleone GF, Ribeiro DA. Low-level laser therapy modulates cyclo-oxygenase-2 expression during bone repair in rats. Lasers Med Sci [Internet]. 2009 Mar 29;24(2):195-201.

18. Magri AMP, Fernandes KR, Kido HW, Fernandes GS, Fermino $S$ de $\mathrm{S}$, Gabbai-Armelin PR, et al. Photobiomodulation guided healing in a sub-critical bone defect in calvarias of rats. Laser Ther. 2019;28(3):1719. 
19. Peccin MS, de Oliveira F, Muniz Renno AC, Pacheco de Jesus GP, Pozzi R, Gomes de Moura CF, et al. Helium-neon laser improves bone repair in rabbits: comparison at two anatomic sites. Lasers Med Sci [Internet]. 2013 Jul 29;28(4):1125-30.

20. Marques L, Holgado LA, Francischone LA, Ximenez JPB, Okamoto R, Kinoshita A. New LLLT protocol to speed up the bone healing processhistometric and immunohistochemical analysis in rat calvarial bone defect. Lasers Med Sci [Internet]. 2015 May 23;30(4):1225-30.

21. Atasoy KT, Korkmaz YT, Odaci E, Hanci H. The efficacy of lowlevel $940 \mathrm{~nm}$ laser therapy with different energy intensities on bone healing. Braz Oral Res [Internet]. 2017;31.

22. Fávaro-Pípi E, Feitosa SM, Ribeiro DA, Bossini P, Oliveira P, Parizotto NA, et al. Comparative study of the effects of low-intensity pulsed ultrasound and low-level laser therapy on bone defects in tibias of rats. Lasers Med Sci [Internet]. 2010 Sep 3;25(5):727-32.

23. Tim CR, Pinto KNZ, Rossi BRO, Fernandes K, Matsumoto MA, Parizotto NA, et al. Low-level laser therapy enhances the expression of osteogenic factors during bone repair in rats. Lasers Med Sci [Internet]. 2014 Jan 21;29(1):147-56.

24. Lopes D, Martins-Cruz C, Oliveira MB, Mano JF. Bone physiology as inspiration for tissue regenerative therapies. Biomaterials [Internet]. 2018 Dec;185:240-75.

25. Reznikov N, Shahar R, Weiner S. Bone hierarchical structure in three dimensions. Acta Biomater [Internet]. 2014 Sep;10(9):3815-26. 26. Heckman JD, Ma JSM. The Cost of Delayed Unions. Bull (Hospital Jt Dis (New York, NY). 1997;56(1):63-72.

27. Einhorn TA, Gerstenfeld LC. Fracture healing: mechanisms and interventions. Nat Rev Rheumatol [Internet]. 2015 Jan 30;11(1):45-54. 28. Al-Aql ZS, Alagl AS, Graves DT, Gerstenfeld LC, Einhorn TA. Molecular Mechanisms Controlling Bone Formation during Fracture Healing and Distraction Osteogenesis. J Dent Res [Internet]. 2008 Feb;87(2):107-18. 29. Claes L, Willie B. The enhancement of bone regeneration by ultrasound. Prog Biophys Mol Biol [Internet]. 2007 Jan;93(1-3):384-98. 30. Victoria G, Petrisor B, Drew B, Dick D. Bone stimulation for fracture healing: What's all the fuss? Indian J Orthop [Internet]. 2009;43(2):117. 31. Barbosa D, Villaverde AGJB, LoschiavoArisawa EÂ, Souza RA de. aser therapy in bone repair in rats: analysis of bone optical density. Acta Ortopédica Bras [Internet]. 2014;22(2):71-4.

32. Hamajima S, Hiratsuka K, Kiyama-Kishikawa M, Tagawa T, Kawahara $M$, Ohta $M$, et al. Effect of low-level laser irradiation on osteoglycin gene expression in osteoblasts. Lasers Med Sci [Internet]. 2003 May 1;18(2):78-82.

33. Hou J, Zhang H, Yuan X, Li J, Wei Y, Hu S. In vitro effects of lowlevel laser irradiation for bone marrow mesenchymal stem cells: Proliferation, growth factors secretion and myogenic differentiation. Lasers Surg Med [Internet]. 2008 Dec;40(10):726-33.

34. Hansson Mild K, Lundström R, Wilén J. Non-ionizing Radiation in Swedish Health Care-Exposure and Safety Aspects. Int J Environ Res Public Health [Internet]. 2019 Apr 2;16(7):1186.

35. Maiman T. Stimulated Optical Radiation in Ruby. Nature. 1960;187(4736):493-4.

36. Lin F, Josephs SF, Alexandrescu DT, Ramos F, Bogin V, Gammill V, et al. Lasers, stem cells, and COPD. J Transl Med [Internet]. 2010;8(1):16.

37. Mester E, Szende B, Gärtner P. [The effect of laser beams on the growth of hair in mice]. Radiobiol Radiother (Berl) [Internet]. 1968;9(5):621-6.

38. Alleman I, Goldberg D. Basics in dermatological laser applications. 42nd ed. Karger; 2011.

39. Chung H, Dai T, Sharma SK, Huang Y-Y, Carroll JD, Hamblin MR. The Nuts and Bolts of Low-level Laser (Light) Therapy. Ann Biomed Eng [Internet]. 2012 Feb 2;40(2):516-33.

40. Fujimoto K, Kiyosaki T, Mitsui N, Mayahara K, Omasa S, Suzuki $\mathrm{N}$, et al. Low-intensity laser irradiation stimulates mineralization via increased BMPs in MC3T3-E1 cells. Lasers Surg Med [Internet]. 2010 Aug;42(6):519-26.

41. Wu J-Y, Chen $\mathrm{C}-\mathrm{H}$, Yeh L-Y, Yeh $\mathrm{M}-\mathrm{L}$, Ting C-C, Wang $\mathrm{Y}-\mathrm{H}$. Lowpower laser irradiation promotes the proliferation and osteogenic differentiation of human periodontal ligament cells via cyclic adenosine monophosphate. Int J Oral Sci [Internet]. 2013 Jun 21;5(2):85-91.

42. Coombe AR, Ho CTG, Darendeliler MA, Hunter N, Philips JR, Chapple $\mathrm{CC}$, et al. The effects of low level laser irradiation on osteoblastic cells. Orthod Craniofacial Res. 2001;4(1):3-14.

43. Huang Y-Y, Sharma SK, Carroll J, Hamblin MR. Biphasic Dose Response in Low Level Light Therapy - an Update. Dose-Response [Internet]. 2011 Oct 2;9(4):dose-response.1.

44. Hamblin MR, Demidova TN. Mechanisms of low level light therapy. In: Hamblin MR, Waynant RW, Anders J, editors. 2006. p. 614001.

45. Kheiri A, Amid R, Kheiri L, Namdari M, Mojahedi M, Kadkhodazadeh M. Effect of Low- Level Laser Therapy on Bone Regeneration of Critical-Size Bone Defects: A Systematic Review of In Vivo Studies and Meta-Analysis. Arch Oral Biol [Internet]. 2020 Sep;117:104782.

46. Escudero JSB, Perez MGB, de Oliveira Rosso MP, Buchaim DV, Pomini KT, Campos LMG, et al. Photobiomodulation therapy (PBMT) in bone repair: A systematic review. Injury [Internet]. 2019 Nov;50(11):1853-67. 47. Spicer PP, Kretlow JD, Young S, Jansen JA, Kasper FK, Mikos AG. Evaluation of bone regeneration using the rat critical size calvarial defect. Nat Protoc [Internet]. 2012 Oct 27;7(10):1918-29.

48. Gomes PS, Fernandes MH. Rodent models in bone-related research: the relevance of calvarial defects in the assessment of bone regeneration strategies. Lab Anim [Internet]. 2011 Jan;45(1):14-24.

49. Schmitz JP, Hollinger JO. The critical size defect as an experimental model for craniomandibulofacial nonunions. Clin Orthop Relat Res [Internet]. 1986 Apr;(205):299-308.

50. Bosch C, Melsen B, Vargervik K. Importance of the Critical-Size Bone Defect in Testing Bone-Regenerating Materials. J Craniofac Surg [Internet]. 1998 Jul;9(4):310-6.

51. Gosain AK, Santoro TD, Song L-S, Capel CC, Sudhakar P V., Matloub HS. Osteogenesis in Calvarial Defects: Contribution of the Dura, the Pericranium, and the Surrounding Bone in Adult versus Infant Animals. Plast Reconstr Surg [Internet]. 2003 Aug;112(2):515-27.

52. Cooper GM, Mooney MP, Gosain AK, Campbell PG, Losee JE, Huard J. Testing the Critical Size in Calvarial Bone Defects: Revisiting the Concept of a Critical-Size Defect. Plast Reconstr Surg [Internet]. 2010 Jun;125(6):1685-92.

53. Kasuya S, Kato-Kogoe N, Omori M, Yamamoto K, Taguchi S, Fujita $\mathrm{H}$, et al. New Bone Formation Process Using Bio-Oss and Collagen Membrane for Rat Calvarial Bone Defect: Histological Observation. Implant Dent. 2018;27(2):1-7.

54. Messora MR, Nagata MJH, Mariano RC, Dornelles RCM, Bomfim SRM, Fucini SE, et al. Bone healing in critical-size defects treated with platelet-rich plasma : a histologic and histometric study in rat calvaria. J Periodontal Res. 2008;43(2):217-23.

55. Wang D, Tabassum A, Wu G, Deng L, Wismeijer D, Liu Y. Bone regeneration in critical-sized bone defect enhanced by introducing osteoinductivity to biphasic calcium phosphate granules. 2016;1-10. 56. Almeida ALPF de, Medeiros IL, Cunha MJS, Sbrana MC, Oliveira PGFP de, Almeida LAE. The effect of low-level laser on bone healing in critical size defects treated with or without autogenous bone graft : an experimental study in rat calvaria. Clin Oral Implants Res. 2013;25(10):1131-6.

57. Efeoglu C, Burke JL, Parsons AJ, Aitchison GA, Scotchford C, Rudd C, et al. Analysis of calvarial bone defects in rats using microcomputed tomography: potential for a novel composite material and a new quantitative measurement. Br J Oral Maxillofac Surg [Internet]. 2009 Dec;47(8):616-21.

58. Vajgel A, Mardas N, Farias BC, Petrie A, Cimões R, Donos N. A systematic review on the critical size defect model. Clin Oral Implants Res [Internet]. 2014 Aug;25(8):879-93.

59. Nyan M, Sato D, Kihara H, Machida T, Ohya K, Kasugai S. Effects of the combination with $\alpha$-tricalcium phosphate and simvastatin on bone regeneration. Clin Oral Implants Res [Internet]. 2009 Mar;20(3):280-7.

60. Lim J, Lee J, Yun H-S, Shin H-I, Park EK. Comparison of bone regeneration rate in flat and long bone defects: Calvarial and tibial bone. Tissue Eng Regen Med [Internet]. 2013 Dec 21;10(6):336-40.

61. McGovern JA, Griffin M, Hutmacher DW. Animal models for bone tissue engineering and modelling disease. Dis Model Mech [Internet]. 2018 Apr 1;11(4):dmm033084.

62. Alberius $P$, Johnell $O$. Repair of intra-membranous bone fractures and defects in rats. J Cranio-Maxillofacial Surg [Internet]. 1991 Jan;19(1):15-20.

63. Zhang P, Wu Y, Dai Q, Fang B, Jiang L. p38-MAPK signaling pathway is not involved in osteogenic differentiation during early response of 
mesenchymal stem cells to continuous mechanical strain. Mol Cell Biochem [Internet]. 2013 Jun 23;378(1-2):19-28.

64. Huiskes R, Ruimerman R, van Lenthe GH, Janssen JD. Effects of mechanical forces on maintenance and adaptation of form in trabecular bone. Nature [Internet]. 2000 Jun;405(6787):704-6.

65. Meng X, Ziadlou R, Grad S, Alini M, Wen C, Lai Y, et al. Animal Models of Osteochondral Defect for Testing Biomaterials. Biochem Res Int [Internet]. 2020 Jan 28;2020(4):1-12.

66. Fan R, Gong H, Zhang R, Gao J, Jia Z, Hu Y. Quantification of AgeRelated Tissue-Level Failure Strains of Rat Femoral Cortical Bones Using an Approach Combining Macrocompressive Test and Microfinite Element Analysis. J Biomech Eng [Internet]. 2016 Apr 1;138(4).

67. Liu X, Lyon R, Meier HT, Thometz J, Haworth ST. Effect of LowerLevel Laser Therapy on Rabbit Tibial Fracture. Photomed Laser Surg [Internet]. 2007 Dec;25(6):487-94.

68. An YH, Friedman R. Animal models in orthopedic research. Boca Raton, FL: CRC Press; 1998.

69. Neyt JG, Buckwalter JA, Carroll NC. Use of animal models in musculoskeletal research. lowa Orthop J [Internet]. 1998;18:118-23.

70. Wang X, Mabrey JD, Agrawal CM. An interspecies comparison of bone fracture properties. Biomed Mater Eng [Internet]. 1998;8(1):1-9.

71. Aerssens J, Boonen S, Lowet G, Dequeker J. Interspecies Differences in Bone Composition, Density, and Quality: Potential Implications for in Vivo Bone Research 1. Endocrinology [Internet]. 1998 Feb;139(2):663-70.

72. Thorwarth M, Schultze-Mosgau S, Kessler P, Wiltfang J, Schlegel KA. Bone Regeneration in Osseous Defects Using a Resorbable Nanoparticular Hydroxyapatite. J Oral Maxillofac Surg [Internet]. 2005
Nov;63(11):1626-33.

73. Raab DM, Crenshaw TD, Kimmel DB, Smith EL. A histomorphometric study of cortical bone activity during increased weight-bearing exercise. J Bone Miner Res [Internet]. 2009 Dec 3;6(7):741-9.

74. Mosekilde L, Weisbrode SE, Safron JA, Stills HF, Jankowsky ML, Ebert DC, et al. Calcium-restricted ovariectomized sinclair S-1 minipigs: An animal model of osteopenia and trabecular plate perforation. Bone [Internet]. 1993 May;14(3):379-82.

75. Swindle MM, Smith AC, Hepburn BJS. Swine as Models in Experimental Surgery. J Investig Surg [Internet]. 1988 Jan 9;1(1):65-79. 76. Newman E. The Potential of Sheep for the Study of Osteopenia: Current Status and Comparison with Other Animal Models. Bone [Internet]. 1995 Apr;16(4):277S-284S.

77. Eitel F, Klapp F, Jacobson W, Schweiberer L. Bone regeneration in animals and in man. Arch Orthop Trauma Surg [Internet]. 1981 Oct;99(1):59-64.

78. Nafei A, Kabel J, Odgaard A, Linde F, Hvid I. Properties of growing trabecular ovine bone: Part II. J Bone Jt Surg [Internet]. 2000 Aug 1;82(6):921-7.

79. den Boer FC, Patka P, Bakker FC, Wippermann BW, van Lingen A, Vink GQM, et al. New segmental long bone defect model in sheep: Quantitative analysis of healing with dual energy X-ray absorptiometry. J Orthop Res [Internet]. 1999 Sep;17(5):654-60.

80. Willie BM, Bloebaum RD, Bireley WR, Bachus KN, Hofmann AA. Determining relevance of a weight-bearing ovine model for bone ingrowth assessment. J Biomed Mater Res [Internet]. 2004 Jun 1;69A(3):567-76.

\section{Mini Curriculum and Author's Contribution}

1. Otavio Marino dos Santos Neto - DDS, MsC, PhD Student. Design of study; search; review and preparation and draft of the manuscript. ORCID: 0000-0002-5220-5409

2. Lothar Lilge - PhD - Design of study; data interpretation; critical review and final approval. ORCID: 0000-0001-5533-0005 3. Carla Andreotti Damante DDS, PhD - Design of study; data interpretation; critical review and final approval. ORCID: 00000002-6782-8596

4. Ana Carla Campos DDS, MsC, PhD Student - Search; preparation and draft of manuscript. ORCID: 0000-0002-9716-8429 5. João Paulo Mardegan Issa DDS, PhD - Guiding professor; data interpretation; critical review and final approval. ORCID: 0000-0002-1056-0795

Received: March 30, 2021.

Accepted: April 4, 2021
Corresponding author

João Paulo Mardegan Issa

Email:jpmissa@forp.usp.br 